\title{
Heart bailout by cell therapy: introducing an acceptable test for comparing cell accountability
}

\author{
Paolo Madeddu* \\ See related research by Barclay et al., http://stemcellres.com/content/3/4/23
}

\begin{abstract}
Cell therapy for cardiovascular disease is still in its initial phase of development and hence stringent studies are now required for comparison between available approaches using validated experimental models. The best cell for regenerative purposes should have the ability to stimulate vascular repair and cardiomyogenesis in a time-programmable fashion, cooperating with reparative processes afforded by resident cells. However, these requirements are often unreachable with individual cell types currently used in clinical trials as documented by an interesting article from Barclay and colleagues in the current issue of Stem Cell Research and Therapy.
\end{abstract}

Cell therapy is an emerging field that promises to help cardiovascular patients to regain normal function. Contemporary approaches rely on subsidising the ischaemic heart and limb muscles with vascular growth factors or stem cells with the hope that encouraging the formation of new blood vessels may eventually result in myocyte salvage/regeneration. Such endeavours proved to be feasible and generally safe, but failed to show an efficacy level comparable to that initially reported in studies on animal models. One reason for these disappointing results could be that current therapies use cells that are not best suited for the purpose. Hence, the concept of cell therapy remains meaningful but incomplete. Comparative studies testing different cell types in the same experimental setting are missing.

The article from Barclay and colleagues [1] provides new fundamental insights into the differential effects of a spectrum of human cells on promotion of angiogenesis and engraftment in vascular structures. The authors employed an animal model of spontaneous neovascularisation to

*Correspondence: madeddu@yahoo.com

Experimental Cardiovascular Medicine, University of Bristol, Bristol BS2 8HW, UK simultaneously compare mononuclear cells from normal peripheral blood and haematopoietic progenitor cell-rich cell sources (umbilical cord blood, mobilised peripheral blood, bone marrow), CD34+-enriched or -depleted subsets of the above, and outgrowth cell populations from these cells. The results are highlighting yet somehow surprising: CD34+ cells from mobilised peripheral blood or umbilical cord blood are the only cells able to promote new vessel growth; however, they do not incorporate into vessels. Conversely, endothelial outgrowth cells incorporate into vessels, without promoting vessel growth. Data from this study confirm that we are far from using an optimal cell product for promotion of therapeutic vascularisation since the most available cells from peripheral blood would simply provide indirect stimulation of the spontaneous angiogenesis process, whereas the more rare population of true endothelial progenitors is angiogenetically inactive. It could be interesting to investigate if a combination of the two populations could be therapeutically utilitarian.

Several caveats need to be considered when interpreting results from this interesting study. First, cells were originated from human healthy donors and injected into an immunodeficient mouse model. Species-related differences could affect the integration of human cells in functional vascular networks. Moreover, it is not clear if human cells from different sources express surface antigens that can differentially affect the cohesion to mouse vasculature. Second, the plug assay does not necessarily reflect the typical environment of an ischemic tissue, with particular reference to the activated state of endothelial cells and the expression of adhesion molecules required for engraftment of donor cells [2]. Therefore, studies in animal models may not be sufficient to draw conclusions on the mechanisms of integration of autologous cells in a clinical setting. Humanized mice for studying human leukocyte integrins in vivo might be useful to address those pressing questions [3] Obviously, clinical trials comparing different cell populations will give a definitive answer.

Since the initial description by Asahara and colleagues [4], the characteristics of cultured endothelial progenitors 
continue to remain uncertain. The same author recently reported that floating cells from primary bone marrow outgrowth are able to form thick/stable tubes, with hypoxia or shear stress inducing further enhancement of these endothelial-like features [5]. Owing to the difference in the procedural isolation of haematopoietic cells from mouse and human bone marrow, it is difficult to conclude if this refined protocol can help us to select optimal angiogenic cells from total human haematopoietic cells. Enrichment using functional assays rather than antigenically based sorting could be useful for this purpose [6].

The status of the donor source is also very important in determining the fate of injected cells. In fact, disease state can impinge upon the integrity of the stem cell niche, thus undermining the final therapeutic effect [7]. In this context, a comparison of different cell types from the same individual could be crucial, although difficult to realise, for designing new cell therapy strategies.

Obviously, when deciding the best cell therapy, other critical issues need to be considered apart from promotion of angiogenesis. Recent studies have highlighted the possibility that circulating calcifying cells might be deeply intertwined in the development of osteoporosis and vascular calcification [8]. Enhanced imaging systems could help to rule out the possibility of calcifications in hearts receiving different types of human cells. Furthermore, the time window for cell harvesting is important as recent evidence indicates that cells released after an ischemic event may comprise inflammatory elements (usually not present in the circulation of healthy subjects) able to colonize the spleen and then give rise to monocytes promoting the progression and instability of vascular atherosclerotic plaques [9].

In conclusion, current approaches for heart bailout with donations of unspecialised cells are inadequate. To this end, rigorous extension of the seminal work of Barclay and colleagues could accelerate the clinical refinement of cell therapy for the benefit of patients.
Competing interests

The author declares that he has no competing interests.

Published: 14 August 2012

\section{References}

1. Barclay GR, Tura O, Samuel K, Hadoke PW, Mills NL, Newby DE, Turner ML: Systematic assessment in an animal model of the angiogenic potential of different human cell sources for therapeutic revascularisation. Stem Cell Res Ther 2012, 3:23.

2. Lee SP, Youn SW, Cho HJ, Li L, Kim TY, Yook HS, Chung JW, Hur J, Yoon CH, Park KW, Oh BH, Park YB: Integrin-linked kinase, a hypoxia-responsive molecule, controls postnatal vasculogenesis by recruitment of endothelial progenitor cells to ischemic tissue. Circulation 2006, 114:150-159.

3. Kim SS, Kumar P, Ye C, Shankar P: Humanized mice for studying human leukocyte integrins in vivo. Methods Mol Biol 2012, 757:509-521.

4. Asahara T, Murohara T, Sullivan A, Silver M, van der Zee R, Li T, Witzenbichler B, Schatteman G, Isner JM: Isolation of putative progenitor endothelial cells for angiogenesis. Science 1997, 275:964-967.

5. Sekiguchi H, li M, Jujo K, Yokoyama A, Hagiwara N, Asahara T: Improved culture-based isolation of differentiating endothelial progenitor cells from mouse bone marrow mononuclear cells. PLoS One 2011, 6:e28639.

6. Kränkel N, Katare RG, Siragusa M, Barcelos LS, Campagnolo P, Mangialardi G, Fortunato O, Spinetti G, Tran N, Zacharowski K, Wojakowski W, Mroz I, Herman A, Manning Fox JE, MacDonald PE, Schanstra JP, Bascands JL, Ascione R, Angelini G, Emanueli C, Madeddu P: Role of kinin B2 receptor signaling in the recruitment of circulating progenitor cells with neovascularization potential. Circ Res 2008, 103:1335-1343.

7. Oikawa A, Siragusa M, Quaini F, Mangialardi G, Katare RG, Caporali A, van Buul JD, van Alphen FP, Graiani G, Spinetti G, Kraenkel N, Prezioso L, Emanueli C, Madeddu P: Diabetes mellitus induces bone marrow microangiopathy. Arterioscler Thromb Vasc Biol 2010, 30:498-508.

8. Fadini GP, Rattazzi M, Matsumoto T, Asahara T, Khosla S: Emerging role of circulating calcifying cells in the bone-vascular axis. Circulation 2012, 125:2772-2781.

9. Dutta P, Courties G, Wei Y, Leuschner F, Gorbatov R, Robbins CS, Iwamoto Y, Thompson B, Carlson AL, Heidt T, Majmudar MD, Lasitschka F, Etzrodt M, Waterman P, Waring MT, Chicoine AT, van der Laan AM, Niessen HW, Piek JJ, Rubin BB, Butany J, Stone JR, Katus HA, Murphy SA, Morrow DA, Sabatine MS, Vinegoni C, Moskowitz MA, Pittet MJ, Libby P, Lin CP, et al:: Myocardial infarction accelerates atherosclerosis. Nature 2012, 487:325-329.

\section{doi:10.1186/scrt123}

Cite this article as: Madeddu P: Heart bailout by cell therapy: introducing an acceptable test for comparing cell accountability. Stem Cell Research \& Therapy 2012, 3:32. 